\title{
Food Resources of Krasnoyarsk Krai: the Possibility of Exports to Countries Participating in Global Projects (Asia - Siberia-Europe)
}

\author{
Vasily V. Kuimov* and Eva V. Shcherbenko \\ Siberian Federal University \\ 79 Svobodny, Krasnoyarsk, 660041, Russia
}

Received 20.09.2016, received in revised form 11.10.2016, accepted 03.11.2016

This article examines the global food market, its development prospects, resources and capabilities of production in ecologically clean regions of Siberia and Krasnoyarsk Krai and their export to the densely populated countries of South and East Asia participating in the implementation of global projects across the New Silk Road. The authors confirm the need for qualitative improvement of the modern food market emergence in the region.

Keywords: food resources, food market, cooperative-integrative networks for regional products promotion.

DOI: 10.17516/1997-1370-2016-9-11-2832-2844.

Research area: economics.

The global food market. Food has always been the most important resource of human activities. This is reflected in the UN continuous attention to the amount of food production, opportunities for food supply and consumption.

On September 25, 2015 in New York at the jubilee session of the UN, 193 Member States of the UN unanimously adopted a new agenda for sustainable development for the period after 2015, that is a global program to eliminate poverty until 2030 and to ensure a sustainable future, which was a logical continuation of the Millennium Declaration and the Millennium Development Goals in force since 2000, the first of which was reduction of hunger and malnutrition in the world (MDG-1) [10].

International organizations such as the World Food Programme (WFP), International Fund for Agricultural Development (IFAD) and the Food and Agriculture Organization (FAO), according to the World Food Summit's position, acknowledged significant results on the food security and the fight against hunger from 2000 to 2015 .

More than 216 million people have been rescued from a life from hand to mouth; 72 countries have already achieved MDG-1 (the fight against hunger); another nine countries are

(c) Siberian Federal University. All rights reserved

* Corresponding author E-mail address: kuimov1945@mail.ru 
The UN Millenium Development Goals (2000), MDG-1

\section{5 ; About $795 \mathrm{mln}$ people do not eat enough}

- $165 \mathrm{mln}$ LESS than in previous decade

- $\quad 216$ mln LESS than in 1990-1992

\section{2 of 129}

developing countries reached MDG-1 in fight against hunger

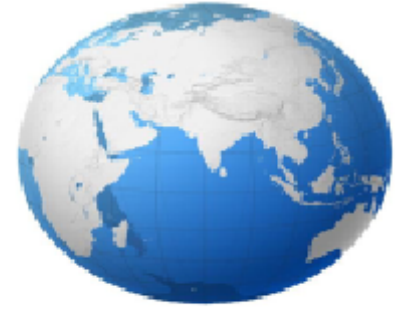

$1 / 9$

of population do

not have the opportunity to get enough food
29

countries halved the number of systematically undernourished people, the task set by the World Food Summit in 1996

Fig. 1. Results of MDG-1 (2000-2015). Compiled by [1, p. 4, 8, 11, 13]

only slightly lagging behind the achievement of this goal, while 29 countries have carried out a more ambitious goal set during the World Food Summit in 1996 - to halve the number of chronically undernourished people (Fig. 1) [1, p. $4,8,11]$.

Seven new goals of Agenda 17 for Sustainable Development for 2015-2030 are directly related to food resourses and hunger reduction [10].

Against the background of the world population growth and the decrease in the number of hungry and malnourished people, there is definitely growing food consumption, increasing demand for new technologies of production, processing, storage and delivery. The Food and Agriculture Organization (FAO) of the UN sees the situation with food as the maintenance of sustainable growing demand and the relative calm in the food market [11, pp. 1-2]

Slight fluctuation of prices for staple foods and stability in imports are expected. Food Price Index in January 2016 amounted to 150.4 points, which is $16 \%$ below the level recorded a year ago and the lowest result since April 2009. The main factors underlying the decline in prices of staple foods are generally abundant supply of agricultural products, the slowdown of the world economy, as well as the strengthening of the US dollar.

The aggregate value of world food imports is to decline in 2015 to $\$ 1.09$ trillion, which is a minimum of five years, according to the FAO. In 2014 , the figure showed a record of $\$ 1.35$ trillion, so the decrease is $19 \%$ [11].

This is mainly due to the decrease in prices and increase in self-sufficiency in a number of countries. The balance of supply and demand for food in 2015-2016 is to remain at a comfortable level for the global market. Supply will be sufficient to meet anticipated demand (Table 1).

In general, due to the increase in world population there will remain steady upward demand for food. The staple foods consumption will grow by $1-2 \%$, enough for the world population growth by $80-100 \mathrm{~m}$ people annually without the deficit in the food market [3]. 
Table 1. World production and trade of staple foods*

\begin{tabular}{|l|c|c|}
\hline \multicolumn{1}{|c|}{ Foodstuffs } & World production in 2015 & $\begin{array}{c}\text { Production in } 2015 \\
\text { as attributable to } 2014\end{array}$ \\
\hline Production: Grain, including wheat & $2.53 \mathrm{bn}$ tons & $-1 \%$ \\
$735 \mathrm{mln}$ tons & $+1.5 \%$ \\
\hline World trade volume: Meat, & $30.5 \mathrm{mln}$ tons & $-0.6 \%$ \\
including poultry & $12.6 \mathrm{mln}$ tons & $-1 \%$ \\
\hline Dairy products & $801 \mathrm{mln}$ tons & $+1.5 \%$ \\
\hline & $168.6 \mathrm{mln}$ tons, including & $+2.6 \%$, including aquaculture \\
Fisheries & aquaculture $-78 \mathrm{mln}$ tons & $+5 \%$ \\
& fish capture $-90.6 \mathrm{mln}$ tons & $+0.7 \%$ \\
\hline The total food imports, trillion dollars & $\$ 1.09$ trillion & $-19 \%$ \\
\hline
\end{tabular}

Compiled by $[11,1]$

Russia and Krasnoyarsk Krai in the world and Russian food market. Russia is becoming an active world exporter of grain and other food products. At the end of 2015 the food export from Russia amounted to more than $\$ 20 \mathrm{bn}$ and exceeded the export volume of the Russian defense industry. According to the FAO experts, due to the dollar high exchange rate in 2015-2016 Russian exporters will show significant activity, and the Russian grain supplies may exceed the record of the previous season (2014-2015), when 37.6m tons of grain were exported [9].

In Russia, on the background of sanctions adopted by a number of countries and retaliatory measures to restrict the import of food products from these countries, there is a process of active development of agricultural production, implying the improvement of the Russian food processing, storage, logistics and trade. In 2014 grain production grew by $12.4 \%$, potato - by $3.0 \%$, vegetables - by 2.3\% (in relation to 2013). In 2015 the indicators were good, too.

Krasnoyarsk Krai enjoys steady development of agricultural production [2, 9] (Table 2).

The analysis shows that the grain sector in the region experiences a constant increase in production; there is a continuous good yield for
Siberian conditions. Cropping and harvest patterns of especially legumes and corn significantly changed. This is due to the rationalization of the animal feed cost, and a considerable reduction in the number of all kinds of animals on the background of the corresponding productivity growth.

Slow growth in population and livestock productivity continue (Table 3 ).

In the past few years the region has seen a momentous decline in the poultry stock. This market remains difficult for new investments. In 2015, however, poultry prices even decreased compared to the past period. One can say that there are no latest technologies which can lead to the increased productivity and lower production costs, as outlined, for example, in the pork production. Against the background of livestock growth and improved productivity there is constant increase in livestock production (Table 4).

Performance in 2015 both in terms of volume and productivity is noticeably better than in the previous periods, but still low for modern conditions and technologies. Overall production in the region has not yet reached the level of 1990 in absolute terms and amount per capita (Tables 4 and 5). 
Table 2. Gross harvest of agricultural crops after processing, farms of all categories in the krai (thous. tonnes) $[3,7]$

\begin{tabular}{|l|c|c|c|c|c|c|c|}
\hline \multicolumn{1}{|c|}{ Item } & 1990 & 2010 & 2011 & 2012 & 2013 & 2014 & $2015^{*}$ \\
\hline Grains and legumes & 2670 & 2086 & 2378 & 1787 & 2215 & 2208 & 2254 \\
\hline $\begin{array}{l}\text { The yield of grain and legumes, hundred } \\
\text { kilograms per hectare }\end{array}$ & 21.13 & 21.30 & 23.70 & 18.10 & 21.50 & 21.3 & 22.0 \\
\hline Wheat & 1316 & 1454 & 1578 & 1162 & 1347 & 1424 & 1515 \\
\hline Legumes & 41.0 & 14.7 & 19.0 & 14.0 & 22.2 & 20.2 & 14.0 \\
\hline Corn for silage, green fodder and hay & 3637 & 176 & 249 & 208 & 267 & 253 & 327 \\
\hline $\begin{array}{l}\text { Field vegetables open and vegetables } \\
\text { under glass }\end{array}$ & 157.0 & 272.3 & 262.3 & 248.3 & 228.6 & 217.2 & 224.7 \\
\hline Potato & 849 & 1254 & 1230 & 1124 & 1085 & 1156 & 1151 \\
\hline
\end{tabular}

* Preliminary data

Table 3. Livestock and poultry in farms of all categories (thous.) [2.9]

\begin{tabular}{|l|c|c|c|c|c|c|c|}
\hline \multicolumn{1}{|c|}{ Item } & 1990 & 2010 & 2011 & 2012 & 2013 & 2014 & $2015^{*}$ \\
\hline Cattle & 1302 & 435 & 439 & 440 & 427 & 425 & 425.1 \\
\hline including cows & 472 & 173 & 175 & 173 & 169 & 169 & 169.7 \\
\hline Pigs & 930 & 424 & 448 & 474 & 446 & 446 & 593.2 \\
\hline Poultry & 9323 & 6058 & 8283 & 8360 & 5343 & 4576 & 4893,2 \\
\hline Sheep and goats & 742 & 54.1 & 52.9 & 53.1 & 51.3 & 53.3 & 57.1 \\
\hline
\end{tabular}

* Preliminary data, January-December 2015

Table 4. Main livestock products [2,9]

\begin{tabular}{|l|c|c|c|c|c|c|c|}
\hline \multicolumn{1}{|c|}{ Item } & 1990 & 2010 & 2011 & 2012 & 2013 & 2014 & $2015^{*}$ \\
\hline Milk production, thous. tons & 1251 & 707 & 724 & 727 & 708 & 725 & 730.2 \\
\hline Milk yield per 1 cow, kg & 2870 & 4107 & 4385 & 4538 & 4314 & 4995 & 5204 \\
\hline $\begin{array}{l}\text { Production of cattle and poultry for } \\
\text { slaughter in live weight, thous. tons }\end{array}$ & 215 & 141 & 142 & 151 & 148 & 187 & 184.4 \\
\hline Egg production, mln & 1008 & 774 & 785 & 859 & 838 & 791 & 823.2 \\
\hline
\end{tabular}

* Preliminary data, January-December 2015

Newelements in the regionalfoodproduction. Dynamics of changes in the food market in the region is associated with both general changes in the world food markets and specific trends in Russian and regional markets. Agricultural production in Russia and in the region, in spite of the high import pressure has retained the potential for development on the whole. Over the past decades, the primary production of crops and livestock has opened up new modern technologies, while the quality of labor is increasing and the chain of production, processing, logistics and retail are constantly improving. The regional employment in agriculture is growing, whereas workers are using modern equipment, thus increasing the livestock productivity. At the same 
Table 5. Production of selected foodstuffs per 1 region's resident (per capita) [2, 9]

\begin{tabular}{|l|c|c|c|c|c|c|c|}
\hline \multicolumn{1}{|c|}{ Item } & 1990 & 2010 & 2011 & 2012 & 2013 & 2014 & 2015 \\
\hline Milk production per capita, kg & 411 & 250 & 255 & 256 & 248 & 256.18 & 258.02 \\
\hline $\begin{array}{l}\text { Meat and poultry production per } \\
\text { capita, kg }\end{array}$ & 71 & 50 & 50 & 53 & 52 & 54 & 55 \\
\hline Egg production per capita & 331 & 274 & 277 & 302 & 294 & 301 & 301 \\
\hline
\end{tabular}

Table 6. The number of employees and salaries in the agricultural sector of Krasnoyarsk Krai [5, 6, 9]

\begin{tabular}{|l|c|c|c|c|c|c|}
\hline \multicolumn{1}{|c|}{ Item } & 2010 & 2011 & 2012 & 2013 & 2014 & $\begin{array}{c}2015 \\
\text { январь- } \\
\text { ноябрь }\end{array}$ \\
\hline $\begin{array}{l}\text { The average monthly nominal salary of employees of } \\
\text { organizations in Krasnoyarsk Krai (rub) }\end{array}$ & 23254 & 25659 & 28672 & 31622 & 34172 & 35040 \\
\hline $\begin{array}{l}\text { The average monthly nominal salary of workers in } \\
\text { agriculture (rub) }\end{array}$ & 11582 & 12978 & 14624 & 15536 & 16926 & 18142 \\
\hline
\end{tabular}

Table 7. The change in the 2015 production of basic food commodities in Krasnoyarsk Krai as attributable to the level of 2014 [4]

\begin{tabular}{|l|c|l|c|}
\hline \multicolumn{1}{|c|}{ Item } & $\begin{array}{c}\% \text { decrease in } 2015 \\
\text { to } 2014\end{array}$ & \multicolumn{1}{|c|}{ Item } & $\begin{array}{c}\% \text { decrease in } 2015 \\
\text { to } 2014\end{array}$ \\
\hline Cereals & $-46.8 \%$ & Poultry and byproducts & $-41,7 \%$ \\
\hline Meat and meat by-products & $-28.0 \%$ & Whole milk products & $-23.2 \%$ \\
\hline Fish and canned fish & $-15.5 \%$ & Non-alcoholic beverages & $-27.3 \%$ \\
\hline Butter & $+8.3 \%$ & Grain flour & $+0.8 \%$ \\
\hline Cheese and cheese products & $+31.2 \%$ & Vodka & $+17.5 \%$ \\
\hline
\end{tabular}

time, rural areas still leave a lot to be desired in terms of living conditions improvement, as the salary in the industry is half of the average salary in the regional economy as a whole (Table 6).

The region is continuing the construction of several large livestock complexes specializing in pork production alongside with the growing range of dairy products, increasing grain export and state support in primary production especially.

At the same time the region is lagging behind in the modern processing, packaging and storage systems, in logistics as regards regional food products. State support system does not encourage cooperation, integration of $\mathrm{AIC}^{1}$ members. Trade in general, federal and regional trade networks, catering, state and municipal procurement systems are not focused on the use of regional food raw materials. Many Russian regions as well as Belarus and partially Kazakhstan (major food exporters) have managed to create integrated systems of interaction and have become highly competitive in promoting their products in the regional market. According to the territorial body of the Federal State Statistics Service of Krasnoyarsk Krai, in 2015 under the aforementioned conditions and despite the yield growth, increased milk production, etc., the food production decreased by $18.8 \%$. In the manufacturing sector of the Krasnoyarsk Krai the share of products shipped to food companies was $4.5 \%$, while in 2014 this share was $5.5 \%$ (Table 7). 
From Table 7 it is clear that cereal production decreased by $46.8 \%$, poultry and byproducts by $41.7 \%$, meat and meat byproducts - by $28 \%$. Volumes of production of dairy products fell by $23.2 \%$, while fish and canned fish production - by $15.5 \%$. Bread and bakery products experienced less than $0.1 \%$ decrease in production, while the beer production fell by $73.7 \%$, non-alcoholic beverages production - by $27.3 \%$, mineral water production - by $7.4 \%$.

Despite this general reduction in the volume of manufactured products there was an increase in production of cheese and cheese products by $31.2 \%$ (earlier they were mostly imported), butter and butter paste - by $8.3 \%$, grain flour production - by $0.8 \%$, vodka production - by 17, 5\%. All these fluctuations have led to the regional food prices' rise by $10 \%$ in 2015 , while it was expected that against the background of the import decrease local producers would not allow this price rise to happen.

Causes of decline and areas for improvements. The analysis showed that a sharp decline in the production of a number of food products in the region (Table 7) mostly occurred alongside with the growth in production of basic raw materials - grain, meat and milk, though it was small (Tables 2, 3, 4, 5, 6). Imports of these goods dropped, while the volume of production remained practically the same. So, the main reasons for the sharp decline in the regional production are replacing local products with the imported ones from other regions of Russia. These trade relationships depend on the management system and relationships between regional producers and processors with retailers and AIC getting state support. Let us look closely at some of these reasons.

The analysis shows that the region is actively developing modern trade practices. Nearly $20 \%$ of the food sales are carried out in up-to-date retail chains, in the cities and some regional centers the stores are located next to people's homes, and the consumers do prefer to buy food with good and informative package, with the indicated certain weight and other data. On the other hand, many regional processors do not have the technology of preparing such regional products. Modern regional logistics centers also prefer to work with stable suppliers of goods, who use modern labeling, packaging and pre-packaging. Both logistics centers and large networks need regular deliveries in dozens of tons. But regional small producers, processors and suppliers cannot do this.

Today commercial networks around the world are developing the production of their own brand goods. Production of name brand goods is made by the order of trading network with the appropriate packaging and labeling of goods for which the network itself guarantees the quality specified. The analysis in these areas shows that many products of networks' own brands in the region (cereals, flour, pasta and others) are bought in the neighboring regions at the processing enterprises which have the new technology and can produce products with stable quality. It is evident that they use their own raw material (grain, meat and milk of the neighboring regions).

The second key point is that a considerable number of brands of food products sold in the region are goods produced by large processors, which use imported raw materials or buy them in the regions where the relevant plants or factories are located. The regional brands have poor awareness and demand. Our observations prove that the local media, a variety of public and not only public controlling organizations show regional products and their producers as low-quality and unfair correspondingly, while the number of local brands is huge. Each manufacturer, who produces 2-3 tons of goods per day, wants to have their own brand and promote it. This is basically impossible. It is necessary to define the regional 
policy with respect to its own products branding and promotion.

Significant amounts of food raw materials are sent for the production of goods produced in large networks and shops, for catering facilities, for government and municipal procurement. And here the lag in cooperation effort has led to a critical reduction in the local products' consumption. Some raw foodstuffs (poultry, beef, eggs, dairy products) are purchased in the neighboring regions, which have a structure capable of organizing periodic delivery with a wide range of goods.

A similar situation is observed in terms of procurement for catering. Current regional small wholesale and logistics centers do not meet the needs of catering industry. Divisions of individual wholesale companies do not provide catering businesses with a comprehensive supply, so they are looking for third-party providers outside the region.

The systems of promotion of regional goods for state and municipal procurement have not been elaborated yet, so the buyers involved have to purchase food from consolidated suppliers in other regions of Russia and Belarus. The regional goods are not bought because of the absence of comprehensive wholesale and logistics centers, which would concentrate the range necessary for the municipal purchases for children's institutions, schools, hospitals, social centers, military units, prisons and penitentiary facilities.

Krasnoyarsk Krai and the Siberian Federal District lack not only the grain export, but also wholesale companies are focused on the delivery of regional food production into other regions of Russia, the countries of the Eurasian Economic Union and other countries, although this would create tremendous opportunities for the development of agro-industrial complex.

The very procurement legislation practically does not allow cooperation of neighboring village food producers and people responsible for municipal or public procurement. Products for the kindergartens are bought in the distribution centers of major cities located at the distance of 100-200 kilometers, which leaves local products without their markets. It is important to emphasize that this concerns large quantities. So according to our analysis, the volume of purchases by laws 44-FZ and 223-FZ in 2014 and the first half of 2015 amounted to more than 4 billion rubles in the region (Table 8).

According to data of the official Russian Federation Internet site, from 1 January 2015 to 1 July 2015 Krasnoyarsk Krai concluded 575 contracts worth a total of 179883502.00 rubles for the supply of cattle (fresh cooled down and chilled) meat by the Federal Law of 04.05.2013 № 44-FZ "On contract system in the procurement of goods, works and services for government and municipal needs". 562 contracts worth a total of 173188259.00 rubles were signed for the supply of cattle meat (sub-frozen, frozen, deep-frozen and defrosted).

Table 8 shows that the volumes of government and municipal procurement are huge, and they could be a stimulus of production development. But the absence of real structures, which would be engaged in the promotion of regional products results in that other regions of Russia occupy a significant share in meeting the demand for regional government and municipal purchases. Figure 2 shows the structure of regional procurement of certain types of food that can be produced entirely in the region for the first half of 2015 (Fig. 2).

The above analysis shows that the region has substantial resources for the further promotion of food products that could serve the village development as a whole. The business community, working in a segment of the regional food market should constantly expands the sales 
Table 8. The volume of government and municipal procurement by enterprises and organizations of the Krasnoyarsk Krai from the list of agricultural products forbidden for import to the Russian Federation

\begin{tabular}{|c|l|c|c|c|}
\hline № & \multicolumn{1}{|c|}{ Name (group of products) } & $\begin{array}{c}\text { Code in Russian } \\
\text { Customs Union } \\
\text { qualifier of foreign } \\
\text { economic activities }\end{array}$ & $\begin{array}{c}\text { Code in All- } \\
\text { Russian qualifier } \\
\text { of products by } \\
\text { economic activity }\end{array}$ & $\begin{array}{c}\text { The amount of } \\
\text { purchases for the } \\
\text { first half of 2015 } \\
\text { (rub) }\end{array}$ \\
\hline 1 & Cattle meat, fresh or chilled & 201 & $15,11,11$ & 179883502.00 \\
\hline 2 & Cattle meat, frozen & 202 & $15,11,12$ & 173188259.00 \\
\hline 3 & Pork, fresh, chilled or frozen & 203 & $15,11,1314$ & 73215563.00 \\
\hline 4 & Milk and milk products & $0401,0402,0403$, & $15,51,2,3,5$ & 2135340146,00 \\
\hline 5 & Vegetables, edible roots and tubers & $0404,0405,0406$ & & 453305428.00 \\
\hline 6 & Sausages and similar meat products & 160100 & $15,13,12$ & 138314447.00 \\
\hline 7 & $\begin{array}{l}\text { Ready-made products including cheeses } \\
\text { and cottage cheese with vegetable fats }\end{array}$ & 1901901100,1901 & $15,51,40$ & 435530209.00 \\
\hline
\end{tabular}

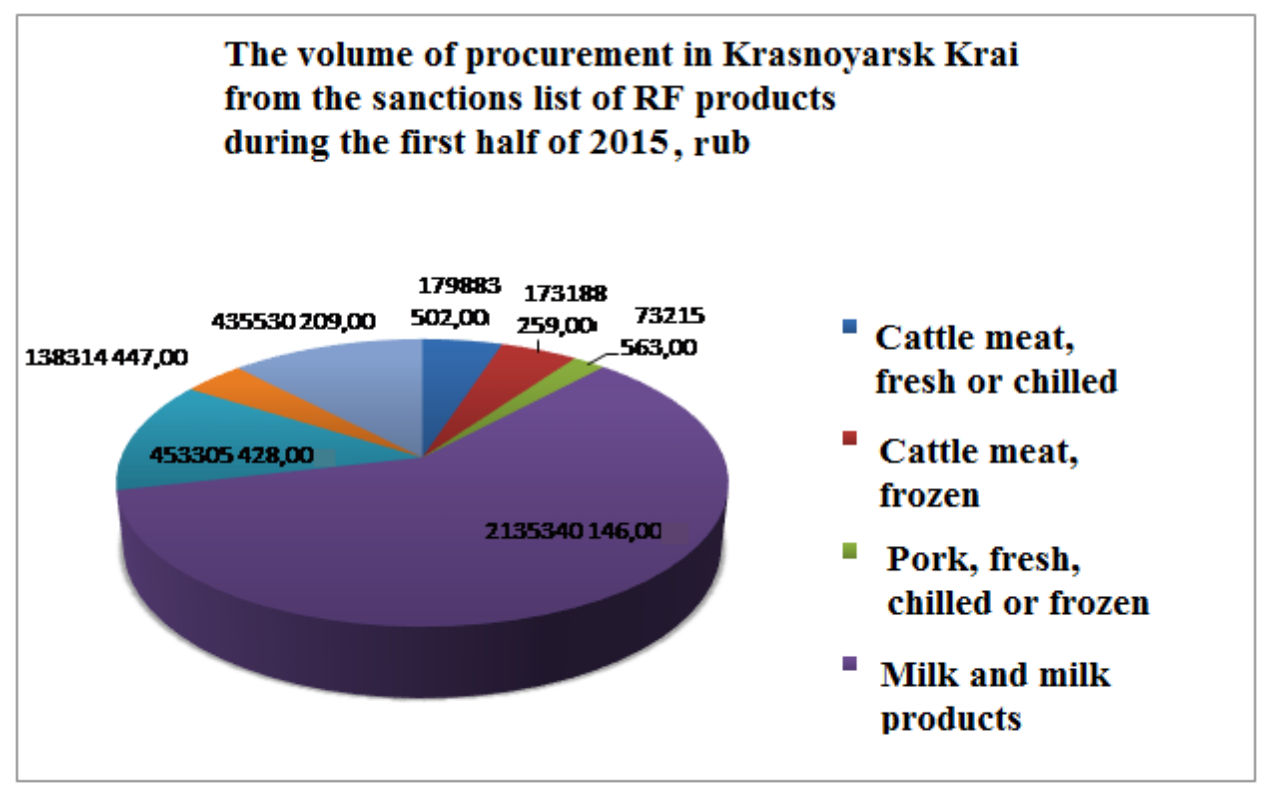

Fig.2. The volume of government and municipal procurement by institutions and organizations of Krasnoyarsk Krai from the sanctions list of RF products during the first half of 2015 (results of our own research)

of its products and searches for expansion of both Russian and export markets.

The markets for food products in Russia and the region. With marvelous opportunities for the production of pure organic products, Siberia and the Krasnoyarsk Krai should focus on the growing markets for these products. In the developed countries (the EU, the US,
Scandinavia) with a high level of income and healthy lifestyle the most demanded are "green" products. But the markets in these countries are saturated with such products. According to the forecast, South-East and Central Asia will be the main regions of growth up to 2030 . Currently, the number of the middle class people in China is almost equal to the entire population 


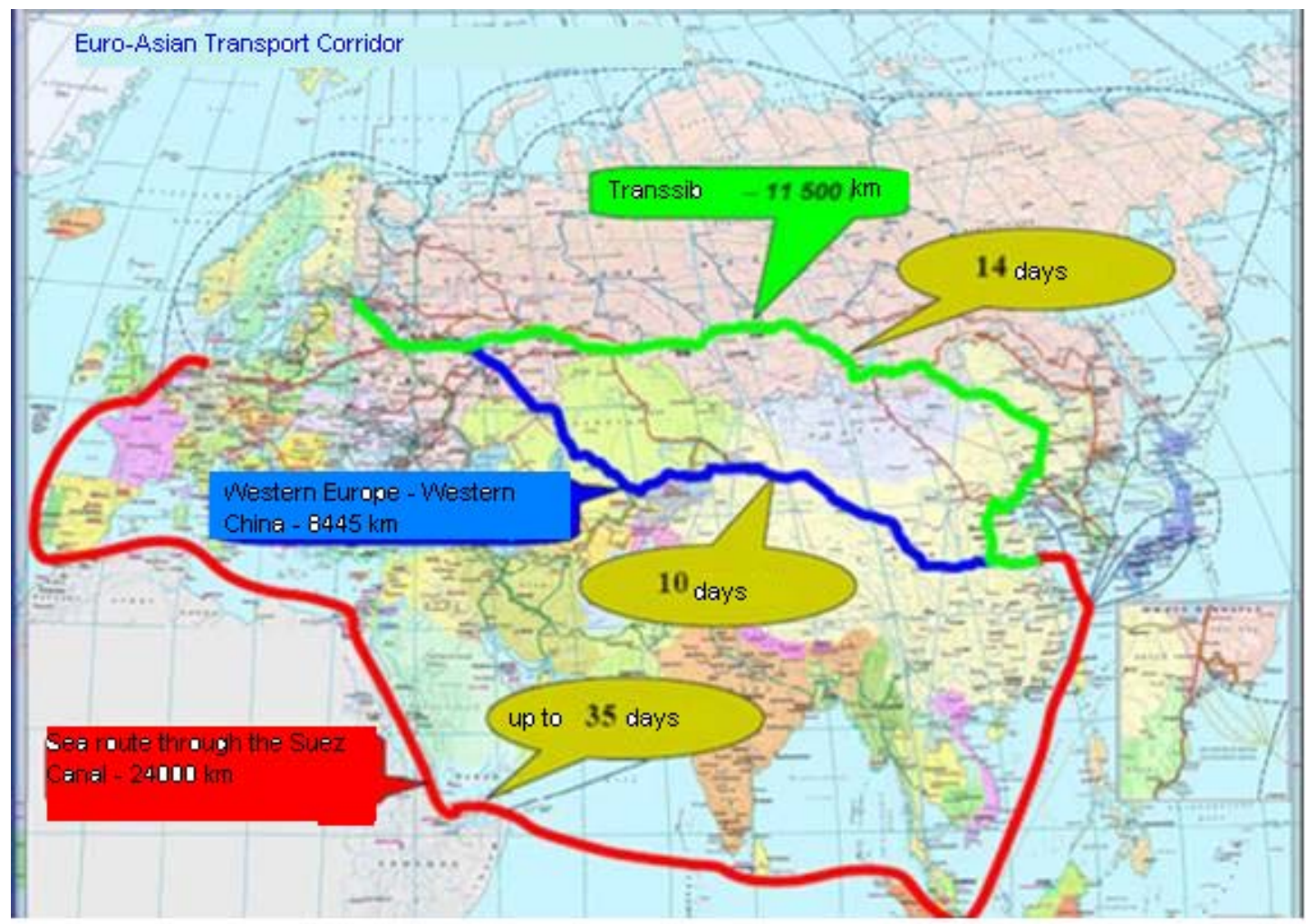

Fig. 3. Routes of the New Silk Road Project

of the EU. The rapid growth of the middle class is predicted in India, Indonesia and other Asian countries. At the same time, competition for resources and markets extensively limits the Russian possibilities to work in the markets of the Euro-Atlantic states. In the $21^{\text {st }}$ century, there is an active development of trade within regional trading blocks (NAFTA, EU and others), while the entry of producers from other trade unions is hindered. In NAFTA, more than half of the US exports is across Canada, Mexico and several Latin American countries. More than $71 \%$ of the EU exports are carried out within the Union. There are new regional associations isolating new countries from their markets. Under the auspices of the US and contradicting the World Trade Organization practices, there appeared Trans-Pacific Partnership (12 countries, 800 million inhabitants), now the transatlantic partnership continues within the NAFTA and the EU countries. All these factors create radical limitations for Russian goods.

This means that Russia will be limited in the choice of markets for exports and it is the most likely to enter the New Silk Road project (more than 30 states and $60 \%$ of the world population) within the framework of APEC, Shanghai Cooperation Organization and the Eurasian Economic Union. Possible deliveries to the places of global projects (the New Silk Road) are shown in Figure 3.

The main routes of the New Silk Road Project are outside the Russian territory, but the delivery time of goods for new routes is less. Meanwhile, the influence of the project New Silk Road is observed in the most populous and rapidly developing countries - China, India, Indonesia, Russia, Vietnam, and others, where there is demand for large amounts of food.

The study of this problem shows that Russian entrepreneurs themselves must actively 
participate in the global projects and deliver the goods to the participating countries along the New Silk Road. More than half of the world's population live here, these countries are growing rapidly and are extremely lacking of water for agriculture, so water use even for human consumption will increase.

Table 9 shows the economic performance of the countries involved in the New Silk Road Project and which import foodstuffs.

Data in Table 9 show that in most of these countries there are opportunities for the development of food trade, including products from Siberia and Krasnoyarsk Krai.

New large companies are necessary to enter new markets. Modern food market is highly competitive. Studies have demonstrated that Siberia and the region itself have a reasonable potential to increase food production. It is important to understand what needs to be done for the promotion of regional products in the Russian and Southeast Asia markets. Our findings so far are disappointing. The most problematic is the fact that almost all the major structures of the food production (trade, processing, logistics, etc.) in the region remain oriented on goods imported from other regions and abroad with the insufficient promotion of regional products.

This has been since the beginning of the 1990s, when the regional inhabitants especially in large cities had relatively high incomes and were willing to buy imported goods, beautifully and conveniently packaged and pre-packaged. Trade, restaurants and cafes were focused on imported goods. Transnational and federal retail chains which came there continued a trend of regional products isolation. A similar process occurred in the logistics system. Regional authorities were proud of these processes and did not pay attention to scientists, warning about the danger of such import dependence, almost to the imposition of sanctions and retaliatory measures of Russia. Neighboring regions of Siberia and many areas of Russia admitted these processes and began to form the chain of interaction between local producers, processors, logistics centers, trade

Table 9. Individual countries' indicators (population, GDP, household incomes)*

\begin{tabular}{|l|c|c|c|}
\hline \multicolumn{1}{|c|}{ Country } & Population, mIn & GDP in US \$ per capita & GDP, millions of US \$ \\
\hline China & 1376,201 & 9350 & 12867390,8 \\
\hline India & 1300,313 & 3574 & 4647559,6 \\
\hline Russia & 146,352 & 15618 & 2285768,9 \\
\hline Iran & 80,1 & 10670 & 854594,4 \\
\hline Tajikistan & 8,6 & 2076 & 17810,1 \\
\hline Uzbekistan & 30,85 & 3453 & 106523,4 \\
\hline Kazakhstan & 17,05 & 13368 & 227891,9 \\
\hline Vietnam & 92,491 & 3616 & 334202,9 \\
\hline Indonesia & 257,132 & 4684 & 1204370,1 \\
\hline Greece & 11,127 & 20710 & 231008,8 \\
\hline Italy & 60,495 & 25463 & 1540361,9 \\
\hline the Netherlands & 16,992 & 35019 & 595062,2 \\
\hline Germany & 79789 & 34847 & 2780404,9 \\
\hline Kyrgyzstan & 6,0 & 3361 & 370,0 \\
\hline
\end{tabular}

* Compiled from data sheets of each country for December 2015 
and catering systems to assist in the formation of large-scale purchasing and marketing associations or agricultural holdings. This was "from field to counter" system with advanced techniques along the whole chain of food movement. This tendency allows them to achieve competitive advantages now. In this respect, Krasnoyarsk Krai lags far behind neighboring territories and especially a major exporter - Belarus, where there are various organizations for processing, storage, preparation, export or sale of goods to other areas.

With the introduction of sanctions and retaliatory measures the network businesses in the region and in the country as a whole were the first to recognize this growing problem and began to form a variety of cooperative structures for procurement, logistics, etc. But even they are working with major suppliers from other regions and countries and are not using regional food production enough.

Further development of food production in the region and its promotion on the Russian and foreign markets is possible only if it is sustainable, based on the formation of reproductive-supply systems, which would integrate business resources, different authorities and areas. These systems should foster cooperation development in the production-trade-marketing structures (clusters), procuring goods from local producers and ensuring their sale for catering, government and municipal procurement, supply to the neighboring regions in Russia and other countries. Our research suggests that the region in view of its territory should be divided into four zones to consolidate the efforts of producers - processors - logistics centers and retail. These zones are Western (with center in Achinsk), Eastern (Kansk), Southern (Minusinsk) and Central (Krasnoyarsk). The consolidation of joint efforts with appropriate state support can be implemented by the already existing regional structures. Such centers will be able to contract production, concentrating its processing facilities for needs of retailers, catering, public procurement, supply to other regions and export. Formation of the modern food market structure is possible on the basis of cooperation of all organizations

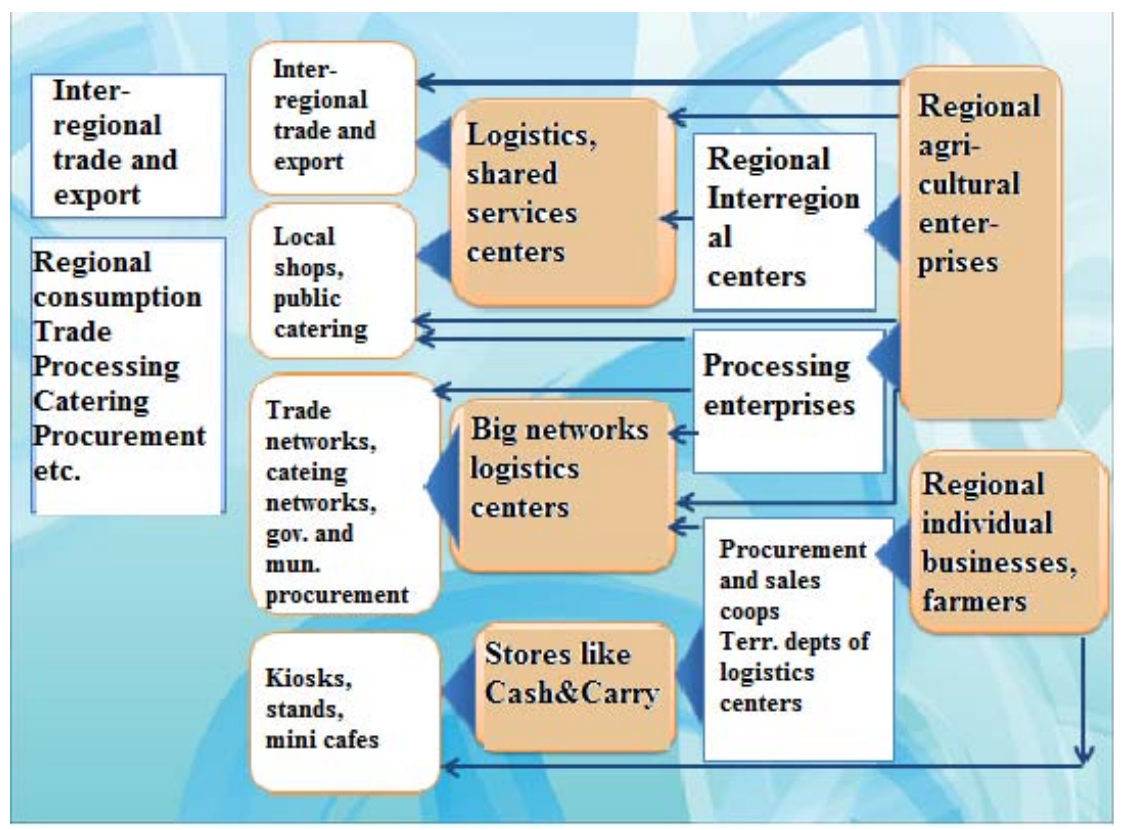

Fig. 4. The structure of the reproduction and sales cooperatives (holdings) of food products 
concerned with obligatory state support. The first results of this integration have already emerged, for example, a co-operative "shop of healthy products", which unites producers and processors, operating under an agreed contract with a major retail chain. Another option is based on the holding structures and is realized by the firm "Sayan Milk". There are several integration structures for the promotion of local vegetables. Each of these options has its own characteristics. It should be noted that so far the annual turnover of each of them is slightly more than one billion rubles, which is not enough. Our research reveals that the new zone structure will be able to compete with the structures in other regions and imported goods, while intentionally promoting the regional development with an annual turnover of 7.12 bln rubles (Fig. 4).

This integrated approach will enable wholesale and logistics centers to draw contracts to buy local production, to ensure advanced preparation of products for deliveries to retail chains and regional individual shops, catering centers, to make delivery for government and municipal procurement possible, to guarantee supplies to other regions of the country and for export. Modern retail chains, department stores, catering businesses, the execution of state and municipal orders, delivery to the regions of Russia and abroad will become integrators for developing marketable products. All these factors will contribute to the development of small and medium enterprises, which in turn will become an integral part of production, processing, trade and marketing systems, i.e. clusters.

Along with this development these programs of integrated development should be included into the regional budget, management and control of state support.

agro-industrial complexes

\section{References}

FAO, IFAD and WFP, 2015. The status of food insecurity in the world - 2015. On track to achieve the 2015 international targets in the fight against hunger: review uneven results. Rome, FAO, $70 \mathrm{p}$.

Firsenko, S.S., Kuz'mina, T.V. (2006). Regional food market of Krasnoyarsk region: the formation, development, inter-regional connections and relationships: a monograph [Regional'nyi prodovol'stvennyi rynok Krasnoiarskogo kraia: formirovanie, razvitie, mezhregional'nye sviazi $i$ otnosheniia: monografiia]. Novosibirsk, Nauka, 320 p.

Food market overview 2015 (2016.) Available at: http://marketing.rbc.ua/news/12.10.2015/7750 (accessed 11 March 2016).

The production of meat and cereals decreased significantly in Krasnoyarsk Krai [V Krasnoiarskom krae znachitel'no sokratilos' proizvodstvo miasa i krupy] (2016). Available at: http://1line.info/ ecomonic/item/52737-proisvodstvo (accessed 11 March 2016).

Kuimov, V. (2014). Marketing technology in the development of food markets of regions of Siberia: a monograph, [Marketingovye tekhnologii v razvitii prodovol'stvennykh tovarov regionov Sibiri: monografiia], ed. by Kuimov, V.V., Suslova, Iu.Iu., Shcherbenko, E., Pankova L.V. Krasnoyarsk, Siberian Federal University, 268 p.

Kuimov, V. (2015). Foodstuffs in Siberia and the World Market: Production and Export of Ecologically Clean Products, In Mediterranean Journal of Social Sciences, 6, 4, 212- 218.

Pilipuk, A.V. (2011). Organization of special trade and sales systems in agricultural complex of Belarus [Organizatsiia firmennykh torgovo-sbytovykh system v agropromyshlennom 
komplekse Belarusi], ed. by V.G. Gusakov. Minsk, Institut sistemnykh issledovanii v APK NAN Belarusi, $173 \mathrm{p}$.

The decree of the Government of Krasnoyarsk Krai dated 30.092013 "On approval of the state program of Krasnoyarsk Krai "Develpment of agriculture and regulation of markets for agricultural production, raw materials and food” for 2014 - 2020 [Postanovlenie Pravitel'stva Krasnoiarskogo kraia ot 30/09/2013 "Ob utverzhdenii gosudarstvennoi programmy Krasnoiarskogo kraia "Razvitie sel'skogo khoziaistva i regulirovanie rynkov sel'skokhoziaistvennoi produktsii syr'ia i prodovol'stviia" na 2014-2020 gody]. Available at: http://krasikc-apk.ru/wp content/uploads/Документы/- (accessed 11 March 2016).

Agriculture of Krasnoyarsk Krai for January-December 2015 [Sel'skoe khoziaistvo Krasnoiarskogo kraia ianvar' - dekabr' 2015].

The agenda for sustainable development for the period until 2030 (2015). Available at: http:// globalcompact.ru/news/utverzhdenyi-novyie-czeli-ustojchivogo-razvitiya (accessed 11 March 2016).

The world food market has calmed down [Mirovoi prodovol'stvennyi rynok uspokoilsia] (2016). Available at: http://newsland.com/user/4297832452/content/4833617 (accessed 11 March 2016).

\title{
Продовольственные ресурсы
}

\section{Красноярского края: возможности экспорта \\ в страны участницы глобальных проектов \\ Азия - Сибирь - Европа}

\author{
В.В. Куимов, Е.В. Щербенко \\ Сибирский федеральный университет \\ Россия, 660041, Красноярск, пр. Свободныій, 79
}

В статье исследуется мировой рынок продовольствия, перспективы его развития, ресурсы и возможности производства продукции в экологически чистых регионах Сибири и Красноярского края и их экспорт в страны - участники реализации глобальных мировых проектов нового шелкового пути, в густонаселенные страны Южной и Восточной Азии. Подтверждается необходимость качественной модернизачии условий становления современного рынка продовольствия в регионе.

Ключевые слова: продовольственные ресурсы, рынки продовольственных ресурсов, коопераичонно-интеграчионые сетевые структуры продвижения региональных товаров.

Научная специальность: 08.00.00 - экономические науки. 